\title{
High selectivity of mutagenic action of synthetic polynucleotides
}

\author{
Yu. N. Alexandrov \\ Institute of Plant Physiology and Genetics National Academy of Sciences of Ukraine \\ 148 Acad. Zabolotnoho vul., Kyiv, 03143, Ukraine
}

\begin{abstract}
Solutions of high molecular weight syntetic polyribo- and polydeoxyribonucleotides of known chemical structure injected into Drosophila melanogaster males caused a 6-17 fold increase of the overall frequency of the recessive lethals in the 2nd chromosome. Complementation analysis of the induced lethals showed an extremely high locus-specificity for some of these mutagens. Possible mechanisms of the mutagenic action of synthetic polynucleotides are discussed.
\end{abstract}

The fact that DNA isolated from various organisms and from DNA-containing viruses is mutagenic for Drosophila and shows a high specificity, inducing mutations preferentially in certain chromosome loci $[1,2]$ led to the supposition that synthetic polynucleotides of sufficient length likewise possess such peculiar mutagenic properties. It seemed possible that this could be true not only for polydeoxynucleotides but also for polyribonucleotides. Some data on the mutagenicity of natural RNA have been previously obtained by Fahmy and Fahmy [3], and in our laboratory it had been shown that RNA-containing viruses are mutagenic for Drosophila and that the mutagenicity of these viruses is highly locus-specific [1]. Moreover, our data led to the conclusion that mutagenicity of viruses schould be probably attributed solely to their nucleic acid and not their proteins. Here we describe the results of experiments on the induction of mutations in Drosophila by ten synthetic polynucleotides of known chemical structure. Fahmy and Fahmy [4] described the mutagenic action for Drosophila of some synthetic polynucleotides but their data are not very convincing as these data are based chiefly on the frequency of Minute mutations which are but weakly expressed so that it is extremely difficult to discern them from wild type.

We tested the mutagenic action the following polynucleotides: three of them, poly $(\mathrm{dA})$, poly $(\mathrm{dT})$ and poly $(\mathrm{dA}, \mathrm{dT})$ were polydeoxyribonucleotides;

(C) Yu. N. ALEXANDROV, 1999 and seven, poly $(A), \operatorname{poly}(I), \operatorname{poly}(U), \operatorname{poly}(A, U)$, $\operatorname{poly}(A, C), \operatorname{poly}(A, I) \operatorname{poly}(A, C, U)$ were polyribonucleotides. All these preparations consisted of a mixture of molecules with a weight from $5 \cdot 10^{5}$ to $16.5 \cdot 10^{\circ}$ Da. Poly (A), poly (A, C), $\operatorname{poly}(A, C, U)$ were manufactured by «Serva» (Germany); poly (U) by «Fluka» (Switzerland); poly (dA, dT) by «Biochemical Inc.» (USA); all other polynucleotides were synthetized in the Institute of Cytology and Genetics (Rossia). Solutions of these preparations in saline $(0.9 \% \mathrm{NaCl})$ were injected into young adult Drosophila melanogaster males of a wild-type stock D 18 standartly used in our laboratory, each male received ca. $0.25 \mu \mathrm{g}$ of one of the polynucleotides dissolved in saline. The males were previously proved to be free from 2 nd chromosome recessive lethals which could have accumulated in the laboratory stock. This was done by making the 2nd chromosome homozygous (using balancers) just before the beginning of our experiments. A search for recessive lethals induced by polynucleotides in the 2nd chromosome of treated males was carried out by the routine $\mathrm{Cl} / \mathrm{L}^{2}$ method. All the lethal-carrying chromosomes were produced by different males, this excluding the possibility of «clustering», i. e. an appearance of several identical lethals as a result of mitotic proliferation of a gonial chromosome. Every lethal was further genetically verified. Control males received injections of saline.

Injection of polynucleotides induced recessive lethals in the 2nd chromosome with a much higher frequency then in the control as shown in Table 1 . 
Table I

Frequency of recessive lethals induced by polynucleotides in the second chromosome

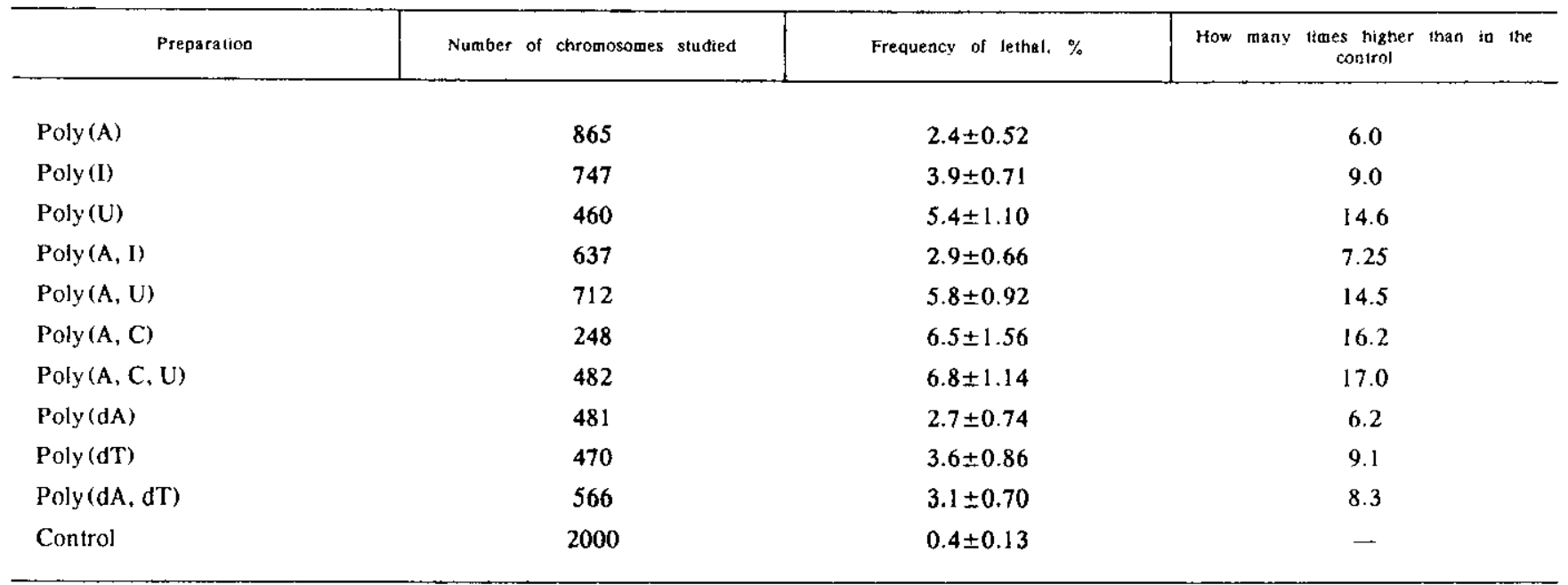

The number of loci in the 2nd chromosome capable of mutating to a recessive lethal condition, according to recent data $[5,6]$, is about $1400-2000$. Our data also show that the number of such loci is well over 1000 . In contradistinction to this, the number of loci in the 2 nd chromosome where recessive lethal mutations were induced by polynucleotides is very much less but in each of these loci mutations arose unusually frequently, just as seen in case of mutations caused by exogenous DNAs [1, 2]. This was established by complementation tests aimed at the determination of the frequency of allelism among the lethals induced by each of the polynucleotides (Table 2).

The minimal number of loci capable of mutating to recessive lethality is inverse to the probability that one such lethal is allelic to another. On the basic of these calculations we can roughly determine the number of loci in the 2nd chromosome which can mutate to recessive lethal condition under the influence of polynucleotides tested. The results are presented in Table 3. For comparison, it is assumed that in the 2nd chromosome there exist some 1600 loci which can mutate to recessive lethality (this number seems to be a fairly good guess).

This method of calculations gives only the lowest number of loci. Their actual number may be somewhat higher because of differencies in mutation rate of different genes and the possible presence of overlapping deletions possessing a recessive lethal effect. But this qualification cannot blur the very great difference between the number of loci which can mutate spontaneously or under the influence of conventional mutagens and the number of loci affected by the polynucleotides tested. The specificity of the mutagenic action of these polynucleotides closely resembles that of the mutagenic action of exogenous DNAs but here it is even more pronounced. Nothing comparable with this extraordinary locus-specificity exists in the action of known physical or chemical mutagens and none of then cause such an enormous increase of the mutation rate of individual loci.

The high specificity of the mutagenic action of synthetic polynucleotides is further confirmed by the peculiar pattern of allelism among mutations caused by them. This pattern is similar to that observed in case of mutations induced by exogenous DNAs. Many lethals are allelic to others which are not allelic to each other. Complementation analysis and mapping of lethals induced by polynucleotides show that this can be attributed to two causes. It seems that rather often several different lethals arise simultaneously in the same chromosome of treated male. In other cases it is possible that the polynucleotides affect several adjecent subunits (sites, neighbouring genes or groups of genes) which can mutate separately or together. Existence of chromosomes with multiple mutations has been proved by the recombination analysis.

The spectra of induced lethal mutations differs for different polynucleotides but this difference is not 
Table 2

Allelism of recessive lethals induced in the second chromosome by polynucleotides

\begin{tabular}{l|c|c}
\hline \multicolumn{1}{c|}{ Preparation } & Number of tethals & Percentage of allectiscs \\
\hline Poly (A) & 21 & $15.2 \pm 2.90$ \\
Poly (I) & 28 & $79.4 \pm 2.00$ \\
Poly (U) & 25 & $0.7 \pm 0.50$ \\
Poly (A, ) & 18 & $57.3 \pm 1.53$ \\
Poly (A, U) & 41 & $21.3 \pm 1.59$ \\
Poly (A, C) & 16 & $6.4 \pm 2.80$ \\
Poly (A, C, U) & 32 & $24.7 \pm 1.46$ \\
Poly (dA) & 13 & $37.2 \pm 5.50$ \\
Poly (dT) & 17 & $0.7 \pm 0.72$ \\
Poly (dA, dT) & 19 & $15.7 \pm 2.90$ \\
Controls: & & $0.0 \pm 4.10$ \\
Spontaneous (our data) & 14 & $0.0 \pm 0.20$ \\
Ethylenimine (our data) & 42 & $0.2 \pm 0.10^{*}$ \\
Spontaneous [7] (data of Ives, 1945) & 102 & $0.3 \pm 0.10^{*}$ \\
Gamma rays [8] (data of Wallace, 1950) & 100 & \\
\hline
\end{tabular}

*Both figures are probably considerably exaggerated. Ives studies lethals found in wild populations where identical recessive mutations are usually frequent bacause of gene draft, and Wallace worked with lethals induced by radiation causing numerous deletions, many of which may include several loci.

Table 3

Approximate frequency per locus of recessive lethals induced by some polynucleotides in the second chromosome

\begin{tabular}{l|c|c|c}
\hline & $\begin{array}{c}\text { Mean number of loci capable of } \\
\text { mutating }\end{array}$ & Frequency of lethals per locus, $\%$ & $\begin{array}{c}\text { How many limes higher than the } \\
\text { spontaneous frequency }\end{array}$ \\
\hline Poly (A) & 6.6 & 0.36 \\
Poly (I) & 1.3 & 3.00 & 1800 \\
Poly (A, C) & 15.5 & 0.42 \\
Poly (dA) & 2.7 & 0.73 \\
Poly (dT) & 142.8 & 0.07 \\
Poly (dA, dT) & 6.4 & 2.45 & 15000 \\
Spontaneous & 1600.0 (assumed) & 0.0002 \\
\hline
\end{tabular}

absolute. Some cases were found when the same lethal was induced in the same locus by two different polynucleotides.

Microscopic investigation of salyvary gland chromosomes and tests on dominant lethals showed that the polynucleotides in our experiments do not induce gross chromosome rearrangements. Evidently, all the recessive lethals found were gene mutations or microscopically indiscernible microdeletions.

At present only speculative explanations may be proposed for the mechanism of mutagenic action of synthetic polynucleotides. Clearly, there exists a close similarity in the action of these mutagens and the mutagenic action of exogenous DNAs. This resem- 
blance is expressed in the very high frequency of gene mutations or microdeletions preferentially induced in a restricted number of chromosome loci; also, in the non-random distribution of mutations along the chromosome and in the absence of gross chromosome rearrangements. A number of considerations led to the supposition that fragments of a foreing DNA become inserted into the chromosome of the recipient but only in such loci to which fragments of a given DNA have some kind of affinity. This view is supported by the fact that DNA of Drosophila itself is also mutagenic for this insect but completely lacks locus-specificity, probably because fragments of Drosophila DNA are homologous to a great number of loci in the DNA of affected chromosomes [1].

The mutagenic action of synthetic polynucleotides studied by us (its high locus-specificity, frequent induction of multimutational events) closely resembles that of exogenous DNAs, this suggesting a common mechanism. However, the hypothetical insertion model proposed by us needs serious amendments to become applicable not only to synthetic polynucleotides of the desoxyribose type but also to the ribose type. This amendment is also needed to explain the mutagenic action of RNA-containing viruses as our experiments showed that their mutagenicity is caused by their RNA (viral proteins complety lacking mutagenic properties). But on theoretical grounds it is absolutely impossible for fragments of ribose polynucleotides or of natural RNAs to be inserted into the chromosomal DNA of recipients. To overcome this difficulty we supposed that not fragments of the molecules of the ribose type are inserted into the chromosomal DNA but their DNA-copies (cDNA) synthetized by reverse transcription in the cells of the recipient; the enzymes necessary for reverse transcription are present in insect cells [9, 101 .

Some doubts about the correctness of this explanation arose after we showed that the spectrum of lethal mutations induced in the 2 nd chromosome of $D$. melanogaster by injection of a solution of synthetic poly (dA) is, against our expectation, suite different from the spectrum of such mutations induced by poly $(d T)$ and that no correlation exist also between the spectra of lethals induced by poly(U) and poly $(\mathrm{dT})$. But eventually we realized that these facts may not contradict our supposition that the mutagenic action of synthetic polynucleotides of the ribose type depends on the formation of their DNA copies by reverse transcription. It is quite possible that an insertion into a gene (or close to it) of a fragment of poly $(\mathrm{dA})$ will change its fine structure quite differently compare to insertion of poly (dT) etc.
A second possible mechanism of the mutagenic action of exogenous DNAs and synthetic polynucleotides should also be mentioned. Alexandrov and Gershenson [11] and Alexandrov [12] supposed that these mutagenes can somehow activate mobile genetic elements present in the Drosophila genome, this leading to their transpositions causing mutations in target loci. In favour of this idea, though indirectly, are the numerous published data on the mutagenicity of mobile genetic elements and especially the results of Gerasimova and her collaborators [13-18] showing that spontaneous multimutational events studied by them in Drosophila are connected with and seemingly caused by simultaneously occuring transpositions of several different mobile genetic elements.

The possible mechanisms discussed above of the mutagenic action of exogenous DNAs and synthetic polynucleotides are not necessarily mutually exclusive and may be complementary. Of course, we fully realise that they are only speculative and their verification, refutation or modification must await an accumulation of additional experimental data. Until then it is perhaps safer to limit ourselves to a vague statement that, perephrasing Green $[19]$, exogenous DNAs and synthetic polynucleotides act as inducers of genomic stress, thereby increasing the occurrence of gene mutations.

Acknowledgements. I am highly indebted to S. M. Gershenson for his interest in this work, everready help, useful suggestions and critical reading of the manuscript.

\section{Ю. М. Александров}

Висока селективність мутагеної дії синтетичних полінуклеотидів Резюме

Високомолекулярні рознини полірибо- ма поліеезоксирибонуклеотидів, шо введено у самців Drosophila melanogaster, збільиували у 6-17 разів пастоту рецесивних летальнних мутацій у 2-й хромосомі. Комплементаційний аналіз індукованих летальних мутацій виявив високу локус-специфінність для цих мутагенів. Обговорюються можливі механізми мутасенної дї синтетичних полінуклеотидів.

\section{Ю. Н. Александров}

Высокая селективность мутагенного действия синтетических полинуклеотидов

Резюме

Растворы полирибо- и полидезоксирибонуклеотидов известной химической структуры и высокой молекулярной массы, инъецированные в самцов Drosophila melanogaster, nовынали в 6-17 раз иастоту рецессивных летальных мутаций во 2-й хромосоме. Комплементационный анализ индуцированных летальных мутаций обнаружил высокую локус-специфичность для этих мутагенов. Обсуждаются возможные механизмы мутагенного действия синтетических полинуклеотидов. 


\section{REFERENCES}

1. Gershenson S. M., Alexandrov $Y u$. N., Maliuta $S . S$. Mutagenic action of DNA and viruses in Drosophila.-Kiyv: Naukova dumka, 1975.-160 pp. (in Russian a. English).

2. Gershenson S. M. Mutagenic action of DNA, insertion, transposition and gene instability // Proc. 14 Int. Congr. of Genet.-Moscow: Mir, 1980.-Vol. 1, book 2.-P. 91-115.

3. Fahmy $O$. G., Fahmy $M$. J. Mutagenic activity of macromolecules in Drosophila melanogaster // Nature. -1962. 196, N 4857.-.P. 873-876.

4. Fahmy O.G., Fahmy M. J. Mutagenesis in relation to nucleic acid synthesis in cellular genetic system // Mechanisms of mutation and inducing factors.-Prague: Academia, 1966.P. $267-282$.

5. Simmons $M . J$. Crow J. F. Mutations affecting fitness in Drosophila populations // Ann. Rev. Genet.-1977.-11.P. $49-78$.

6. Abrahamson S., Wurgler E. F., De Jong C., Meyer H. U. How many loci on the X-chromosome of Drosophila melanogaster can mulate to recessive lethals? // Envirom. Mutagens.1980.-2.-P. $447-453$.

7. Ives $P . T$. The genetic structure of American populations of Drosophila melanogaster // Genetics.-1945.-30.-P. 167196.

8. Wallace B. Allelism of second chromosome lethals in Drosophila melanogaster // Proc. Nat. Acad. Sci USA. - 1950.36, N 11.-P. 645-657.

9. Cohen L. H., Penner P. E., Loeb L. A. Multiple DNA polymerases displayed by isoelectric focusing // Ann. N. Y. Acad. Sci. - 1973.-209, N 1.-P. 354-362.

10. Margulies $L$, Chargaff $E$. Survey of DNA polymerase activity during the early development of Drosophila melanogaster i/ Proc. Nat. Acad. Sci USA.-1973.-70, N 10.-m-P. 29462950.

11. Alexandrov $Y u$, Gershenson S. M. Mutagenic action of natural and synthetic polynucleotides and the problem of directed mutations // Zhurn. Obsh. Biol. -1982. -43, N 6.-P. 747763 (in Russian).

12. Alexandrov $Y u$. N. Natural and synthetic polynucleotides of selective action // Mutagenic action of natural and synthetic polynucleotides / Ed. V. V. Morgun.-Kiev: Nauk. Dumka, 1988.-P. 4-10 (in Russian).

13. Gerasimova $T$. I., Jlyin Yu V., Misrokhi L. I., Semenova $L$ $\boldsymbol{V}$., Georgiev $\boldsymbol{G}$. P. A direct demonstration of transposition of a mobile element and its role in the appearance of unstable mutations in Drosophila // Dok!. Akad. Nauk SSSR.-1983.271.-P. 977-980 (in Russian).

14. Gerasimova T. I., Mizrokhi L. Yu., Georgiev G. P. *Transposition bursts» in individual germ cells during genetic destabilization in Drosophila melanogaster // Dokl. Akad. Nauk SSSR.1984.-274, N 6.-P 1473-1476 (in Russian).

15. Gerasimova T. I. Transposition of mobile elements and their role in insertion mutagenesis in Drosophila // Stability and variability of the genome. - Moscow: Nauka, 1985.-P. $26-39$ (in Russian)

16. Gerasimova T. I., Mizrokhi L. Yu, Obolenkova L. A. Georgiev $G$. P. Directed mutagenesis under the influence of mobile elements in unstable strains of Drosophila melanogaster // Dokl. Akad. Nauk SSSR. - 1985.-280.-P. 1246-1250 (in Russian).

17. Gerasimova T. I., Mitin V. A., Tchuricov N. A., Kochieva E $Z$. Site-specific mutagenesis in the cut locus of Drosophila melanogaster under the influence of mobile element mdg4 // Dokl. Akad. Nauk SSSR.-1988.-300.-P. 462-464 (in Russian).

18. Gerasimova T. J., Ladvishenko A. B., Mogila V. A., Georgieva S. G., Kiseleva S. M., Maxymiv D. V. Transposition bursts and chromosome rearrangements in unstable Drosophila strains // Genetika.-1990.-26.-P. 391-411 (in Russian)

19. Green $M . M$. Mobile elements and spontaneous gene mutations // Bambury Rep. 30: Eukaryotic transposable elements as mutagenic agents.- New York: Cold Spring Harbor Iab., 1988.-P. $41-50$. 